\title{
THE EFFECT OF SPLANCHNIC SYMPATHECTOMY IN HYPER- TENSIVE PATIENTS UPON ESTIMATED HEPATIC BLOOD FLOW IN THE UPRIGHT AS CONTRASTED WITH THE HORIZONTAL POSITION ${ }^{1}$
}

\author{
BY ROBERT W. WILKINS, JAMES W. CULBERTSON,2 AND FRANZ J. \\ INGELFINGER \\ (From the Robert Dawson Evans Memorial, Massachusetts Memorial Hospitals, and the De- \\ partment of Medicine, Boston University School of Medicine, Boston, Mass.)
}

(Submitted for publication June 2, 1950; accepted, January 2, 1951)

\section{INTRODUCTION}

It has been found that when normotensive or hypertensive subjects are tilted passively into an upright position estimated hepatic blood flow (EHBF) (2) decreases and calculated hepatic portal resistance (HPR) increases (3). These changes were assumed to be due to active splanchnic vasoconstriction, probably mediated over the splanchnic sympathetic nervous system. Direct evidence bearing on this assumption became available in some of the hypertensive patients undergoing splanchnic sympathectomy and subsequently studied by the same methods as before operation. Such studies are the basis of the present report.

\section{METHOD}

The method was identical with that used in the preoperative studies already reported (3). The first postoperative study was usually done within two weeks after the completion of the second stage of the splanchnicectomy, and, if possible, a second within 12 months. In addition, a few patients were studied one to nine years after (but not before) operation. The type of sympathectomy, unless otherwise noted in Table I, was the lumbodorsal (thoracolumbar) splanchnicectomy of Smithwick (4). After operation some patients 3 were unable to stand for any considerable length of time at a $75^{\circ}$ tiit without marked postural hypotension and symptoms of faintness. Therefore, they were tilted back either to less marked angles (as noted in Table I) that they could tolerate long enough for reliable observations to be made, or to the horizontal position where paired samples of blood were drawn immediately for measurement of EHBF

\footnotetext{
1 Presented in part May 5, 1947 at the Thirty-Ninth Annual Meeting of the American Society for Clinical Investigation, Atlantic City, New Jersey (1).

2 Public Health Service Special Research Fellow of the National Heart Institute. Present address-University Hospitals, Iowa City, Iowa.

3 No patient was allowed to wear his abdominal pressure girdle or elastic stockings during the test.
}

which, because of the time lag previously found to occur in this situation (3), was related to the upright period just before the tilt-back.

\section{RESULTS}

After lumbodorsal splanchnicectomy postural hypotension occurred to some extent in almost all the patients, particularly early after the operation. If it appeared suddenly it resulted not only in less accurate measurements of arterial pressure (which varied from moment to moment as the patient sighed or moved), but also in other technical difficulties, since it made it necessary hurriedly to terminate the period of upright posture, rather than leisurely to proceed until a more steady state of EHBF had been achieved. For these reasons the results in these instances were considered less reliable as equilibrium values than those observed when the patient was able to stand without great difficulty for a considerable period of time. ${ }^{4}$

In all cases after splanchnicectomy there were more nearly proportional decreases of EHBF and mean (one-half systolic plus diastolic) arterial pressure in the upright position (Table I) than before operation when relatively large reductions of hepatic blood flow and small changes of arterial pressure were usually found (Table II). Therefore, after operation calculated hepatic portal resistance (HPR) was often unchanged in the upright position whereas before operation it was usually increased. Thus, comparing average equilibrium figures, HPR in eight splanchnicectomized hypertensive patients increased on tilting from 6.8 to only 7.2 , or $6 \%$ (which is not significant statistically), whereas in nine unoperated hy-

4 Only those data obtained after four minutes in a given position and without fainting are included in the statistical analysis in Table II. 
SPLANCHNIC SYMPATHECTOMY: EFFECT ON HEPATIC BLOOD FLOW

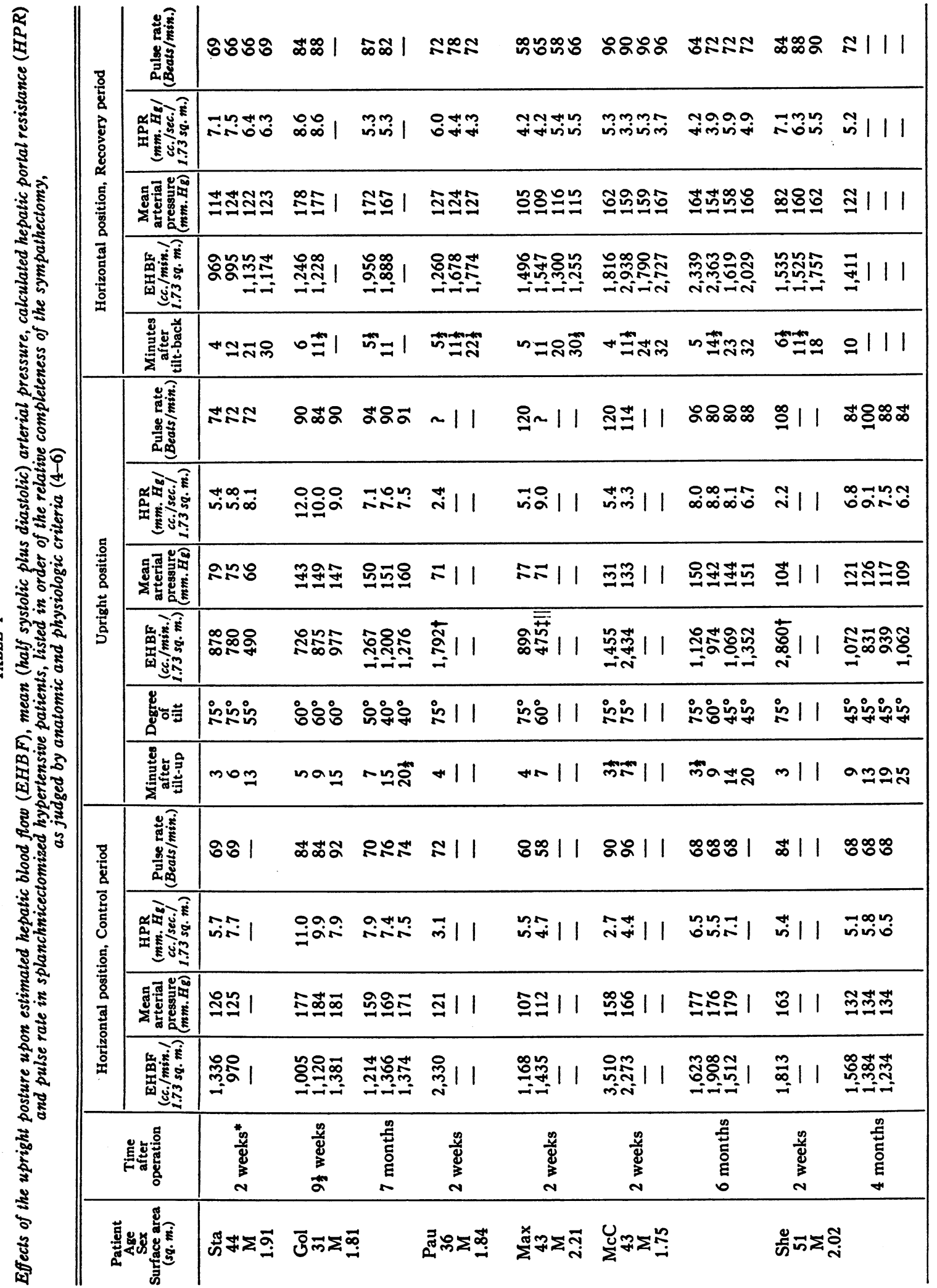




\begin{tabular}{|c|c|c|c|c|c|c|c|c|c|}
\hline \multirow{5}{*}{ 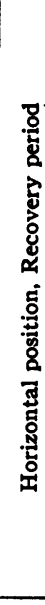 } & 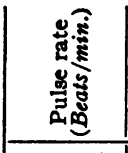 & ガనळ & ะํ & กัณผ & 8̊̊̊口 & ハボ & ตีดิ์ & ஃส I & \multirow{6}{*}{ 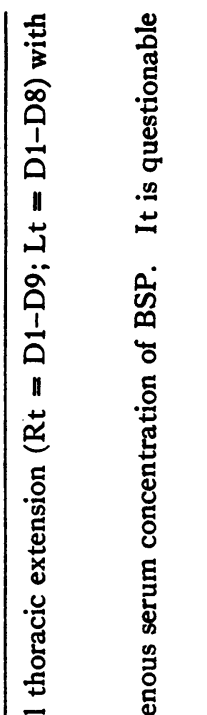 } \\
\hline & 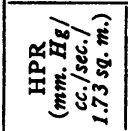 & 업ำ & 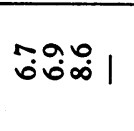 & कूกิ & miñ & $\stackrel{-1}{\circ}$ & 임ํำ & 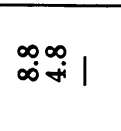 & \\
\hline & 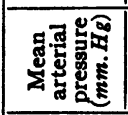 & 恄云吕 & 워임 & సిత్సిః & 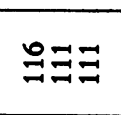 & ్ㅗㅋ & 导き桴 & ్లై | & \\
\hline & 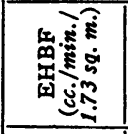 & 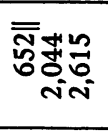 & 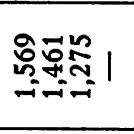 & 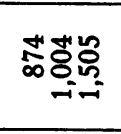 & 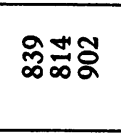 & స̃ํㅠ & 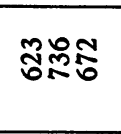 & $\stackrel{+\infty}{\stackrel{\infty}{*}}$ | & \\
\hline & 总总 & $m a 0$ & $\exists \underset{n}{ } \mid$ & 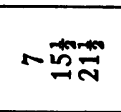 & 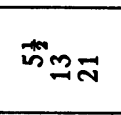 & $\exists \hat{N}$ & 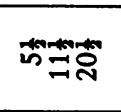 & +芯। & \\
\hline \multirow{6}{*}{ 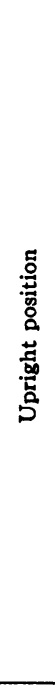 } & 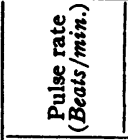 & ลธ్లి। & パハカガ & $\sim \mid 1$ & ৪ঃ। & $\sim 1$ & 䒠 1 & $\stackrel{2}{2} \mid 1$ & \\
\hline & 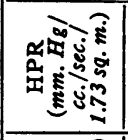 & $\vec{b} \ddot{m} \mid$ & 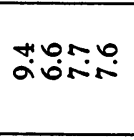 & $\sim 11$ & ஸै? & $\sim 1$ & å| 1 & $\approx 11$ & 焉 \\
\hline & 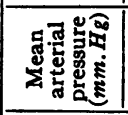 & 闬茎 | & 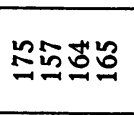 & 211 & $\stackrel{\infty}{\circ}$ & $\sim 1$ & $\stackrel{\Xi}{\beth} \mid 1$ & $\infty||$ & $\begin{array}{l}\Xi \\
\Xi \\
. \Xi\end{array}$ \\
\hline & 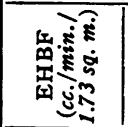 & $\underset{\substack{\infty \\
\sim}}{\stackrel{\infty}{*} \mid}$ & 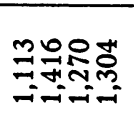 & 离| & 조유| & $\stackrel{+}{\leftrightarrows}$ & $\stackrel{\circ}{\circ} \mid$ & ㅇำ। & 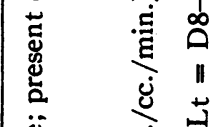 \\
\hline & 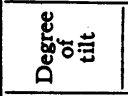 & inin 1 & iniำin & in 11 & inin 1 & in 1 & iㅗㅇ $\mid 1$ & $i 11$ & 竎 \\
\hline & 总总鱼 & $\operatorname{tin} 1$ & $r=\overrightarrow{0} \vec{N}$ & $m \mid 1$ & ำเ & 01 & +11 & m| 1 & 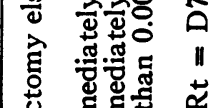 \\
\hline \multirow{4}{*}{ 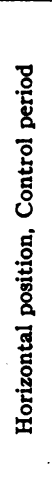 } & 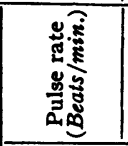 & $-\infty \infty 1$ & เดิเ & $-\infty \infty 1$ & จำเ & ๓ะ & 8ำ: & நొది & \multirow{6}{*}{ 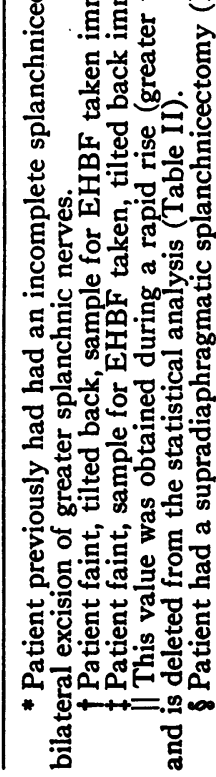 } \\
\hline & 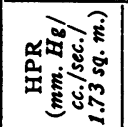 & जिंबे। & |cọ | & 至苏। & ஸै:1 & जी & 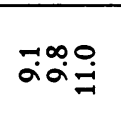 & 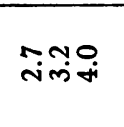 & \\
\hline & 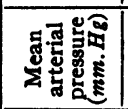 & ్ㅜㄹㅇㅣ & 유리 & ำ 1 & ๖๕్ & लm & 哭点 & 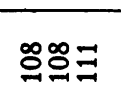 & \\
\hline & 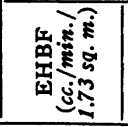 & 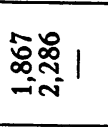 & 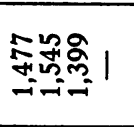 & 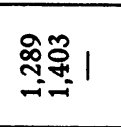 & ํํ이 & กีล & 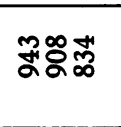 & 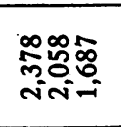 & \\
\hline & 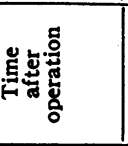 & 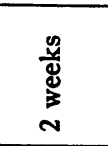 & 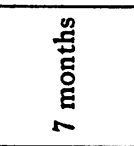 & 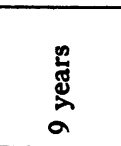 & 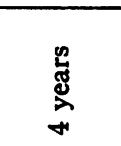 & $\stackrel{2}{\beth}$ & 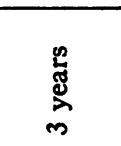 & 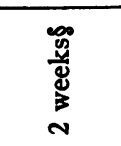 & \\
\hline & 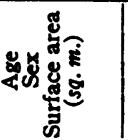 & 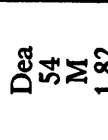 & & & ה & & ๓ొ็ & ప్ర్లిన్త & \\
\hline
\end{tabular}


$\max$

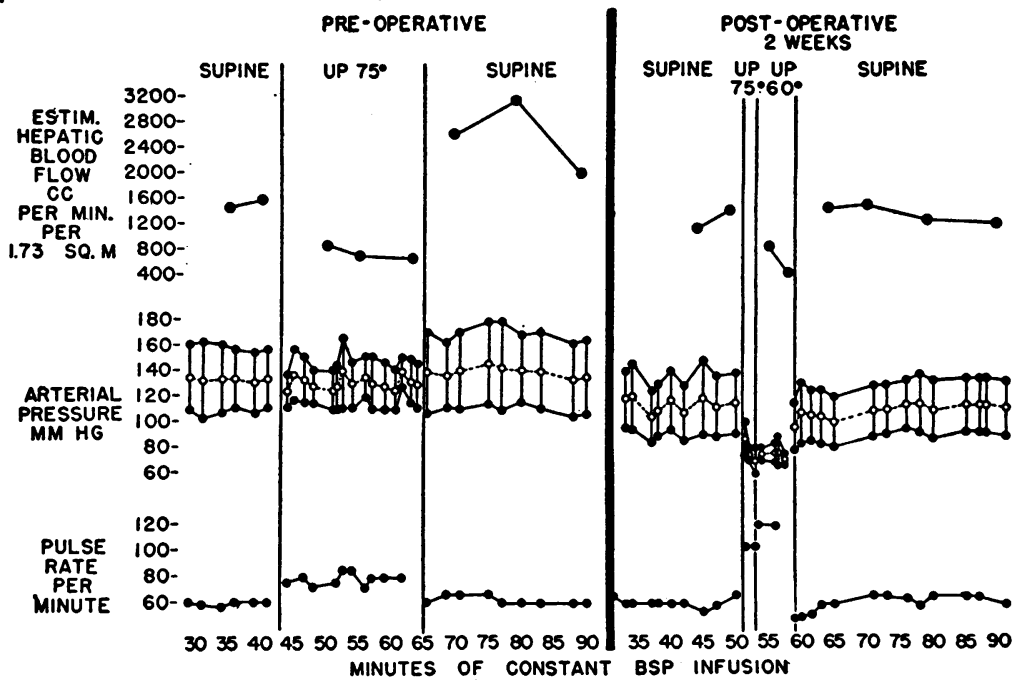

Fig. 1. Chart of EHbF, Arterial Pressure and Pulse Rate of a Hypertensive Patient (MaX), Studied in the Horizontal and Upright Positions BEFORE AND AFTER a Lumbodorsal Splanchnicectomy

"Mean" (half systolic plus diastolic) arterial pressure is indicated by the open circles and interrupted lines. During and after the upright position in the preoperative test, this patient had a marked anxiety reaction that began with a severe headache.

pertensive patients it increased from 7.3 to 10.1 , or $38 \%$ (which is highly significant statistically).

The findings in the splanchnicectomized group may also be demonstrated by charts of experiments done on individual cases before and after operation (Figures 1,2). Here the reductions of EHBF

TABLE II

The effect of splanchnicectomy on the mean* responses of the estimated hepatic blood flow (EHBF), arterial pressure and hepatic portal resistance (HPR) to upright tilting of the body

\begin{tabular}{|c|c|c|c|c|c|c|c|c|c|}
\hline & \multicolumn{3}{|c|}{$\underset{(c c . / m i n . / 1.73 \text { sq. m. })}{\text { EHBF }}$} & \multicolumn{3}{|c|}{$\begin{array}{c}\text { Mean } \S \text { arterial pressure } \\
(\mathrm{mm} . \mathrm{Hg})\end{array}$} & \multicolumn{3}{|c|}{$\begin{array}{c}\text { HPR } \\
\left(\mathrm{mm} . \mathrm{Hg}_{\mathrm{g}} / \mathrm{cc} . / \mathrm{sec} . / 1.73 \text { sq. m. }\right)\end{array}$} \\
\hline . & $\begin{array}{l}\text { Horizontal } \\
\text { (Control) }\end{array}$ & Upright & $\begin{array}{l}\text { Horizontal } \\
\text { (Recovery) }\end{array}$ & $\begin{array}{l}\text { Horizontal } \\
\text { (Control) }\end{array}$ & Upright & $\begin{array}{l}\text { Horizontal } \\
\text { (Recovery) }\end{array}$ & $\begin{array}{l}\text { Horizontal } \\
\text { (Control) }\end{array}$ & Upright & $\begin{array}{l}\text { Horizontal } \\
\text { (Recovery) }\end{array}$ \\
\hline $\begin{array}{l}\text { Splanchnicectomized patients } \\
\text { (11 experiments on } 8 \text { patients) } \\
\text { Mean } \\
\text { Standard Error of Mean } \\
\text { Mean Difference } \dagger \\
\text { Significance of Difference (P) } \ddagger\end{array}$ & $\begin{array}{c}1,472 \\
176 \\
-\end{array}$ & $\begin{array}{r}1,171 \\
163 \\
-301 \\
<0.01\end{array}$ & $\begin{array}{r}1,521 \\
172 \\
+360 \\
<0.01\end{array}$ & $\begin{array}{r}149 \\
8 \\
-\end{array}$ & $\begin{array}{r}125 \\
9 \\
-24 \\
<0.01\end{array}$ & $\begin{array}{r}148 \\
8 \\
+23 \\
<0.01\end{array}$ & $\begin{array}{l}6.8 \\
0.6 \\
- \\
-\end{array}$ & $\begin{array}{c}7.2 \\
0.6 \\
+0.4 \\
0.09\end{array}$ & $\begin{array}{c}6.6 \\
0.8 \\
-0.5 \\
0.44\end{array}$ \\
\hline $\begin{array}{l}\text { Unoperated hypertensive } \\
\text { patients }(\mathbf{n}=9) \\
\text { Mean } \\
\text { Standard Error of Mean } \\
\text { Mean Difference } \dagger \\
\text { Significance of Difference }\end{array}$ & $\begin{array}{r}1,357 \\
97 \\
- \\
-\end{array}$ & $\begin{array}{r}960 \\
68 \\
-397 \\
<0.01\end{array}$ & $\begin{array}{r}1,417 \\
172 \\
+428 \\
<0.05\end{array}$ & $\begin{array}{r}158 \\
7 \\
- \\
-\end{array}$ & $\begin{array}{r}157 \\
7 \\
-1 \\
0.78\end{array}$ & $\begin{array}{r}155 \\
8 \\
0 \\
0.97\end{array}$ & $\begin{array}{l}7.3 \\
0.6 \\
-\end{array}$ & $\begin{array}{r}10.1 \\
0.7 \\
+2.8 \\
<0.01\end{array}$ & $\begin{array}{c}7.2 \\
0.7 \\
-2.4 \\
<0.01\end{array}$ \\
\hline
\end{tabular}

* The mean values of EHBF, arterial pressure and HPR for the group were calculated from the averages of the observations on each individual. See Table I for details of splanchnicectomized patients, and the preceding paper (3) for unoperated hypertensive patients.

$\dagger$ Differences refer to the changes from the immediately preceding position.

$¥$ The significance of the difference was calculated by the method of Fisher for unique samples (8). P values of 0.05 or less (bold type) denote "significant" differences, and values of 0.01 or less "highly significant" differences.

Average of systolic and diastolic pressures. 


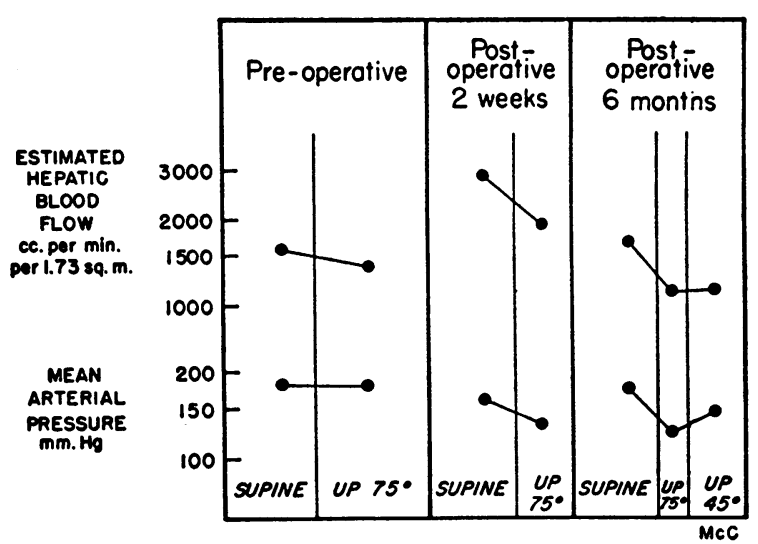

Fig. 2. Chart of Average eHbF and "Mean" (Half Systolic plus Diastolic) Arterial Pressure in the Horizontal and Upright Positions in a Hypertensive Patient (McC) before, Two Weeks after, and Six Months after Lumbodorsal Sympathectomy

in the upright position before operation are seen to be essentially unrelated to changes in arterial pressure, whereas after operation they were usually associated with sizeable decreases in arterial pressure.

After return to the horizontal position the $\mathrm{EHBF}$ in post-operative, as in preoperative, patients usually returned toward, to, or above the previous horizontal control values. Arterial pressure recovered from postural hypotension and calculated HPR did not change significantly (Table II).

\section{DISCUSSION}

The results reported here indicate that the splanchnic sympathetic nervous system of hypertensive patients probably mediates, at least in part, the vasoconstrictor response in the hepatic portal circulation to the upright posture. Thus, sizeable increases in HPR usually did not occur in the upright position after splanchnicectomy, whereas in the same subjects before operation and in normotensive control subjects (3) they did occur. Obviously this does not prove that the changes in EHBF found after splanchnicectomy were only passive and due solely to associated changes in arterial pressure. However, since the decreases in $\mathrm{EHBF}$ in the upright position were no greater after than before operation, whereas the reductions in arterial pressure were much greater, one may assume that there was relatively much less active vasoconstriction in the hepatic-portal region after than before operation. These results give direct confirmation to independent hemodynamic studies in this laboratory which have shown that reflex vasopressor responses to certain blood-pressurelowering stimuli, including the upright posture, are greatly reduced after splanchnicectomy $(5,6)$.

Besides elucidating the influence of the sympathetic nervous system upon hepatic-portal blood flow, these studies indicate the importance of hydrostatic factors, particularly of orthostatic arterial hypotension, upon EHBF. Decreases in arterial pressure, if sizeable, were usually associated with sizeable reductions of EHBF in sympathectomized patients. On the other hand, when minor changes of arterial pressure such as those usually encountered in normotensive or unsympathectomized hypertensive patients in the upright position occurred in splanchnicectomized patients they were associated with little change in EHBF.

Although for the reasons just given, both the activity of splanchnic sympathetic nervous system and the level of the arterial pressure appear to be important factors in the normal regulation of EHBF, other influences also must be assumed to play a role. Thus, even in well-sympathectomized patients, major "spontaneous" changes in EHBF occurred, particularly during and after orthostasis, that could not be accounted for on the basis of the first two factors alone. For example, after standing upright and being returned to the horizontal position some postoperative patients (Gol, $\mathrm{McC}$, and Dea) had large increases in horizontal EHBF which could not be explained by rises in arterial pressure.

The observations made in patients during orthostatic syncope are also of interest in this connection. As mentioned in a previous paper (3), the tendency to collapse in the upright position before operation seemed usually related directly to the absolute level to which hepatic-portal blood flow fell. Thus, when EHBF fell to $750 \mathrm{cc} . / \mathrm{min}$. and failed to recover, collapse was usually imminent even though the arterial pressure up to that point had been well-sustained. After splanchnicectomy, however, while patients in the upright position usually had a lower arterial pressure and a proportionate decrease in EHBF (at times below $750 \mathrm{cc}$./ min.), the expected circulatory "decompensation" characteristic of vaso-vagal syncope did not always appear (notably in Sta). On the other 
hand, three splanchnicectomized patients ( $\mathrm{Pau}$ She and Yof) fainted while EHBF remained good and calculated HPR actually decreased.

The results of these studies provide probably valid indications of the physiologic role of the intact splanchnic sympathetic nervous system, not only in hypertensive but perhaps also in normotensive individuals with respect to the regulation of hepatic-portal blood flow. Along with other observations in this laboratory, they suggest that the sympathetic nervous system normally plays a vasoconstrictor role in the hepatic-portal circulation. The vasoconstrictor and vasodilator influences in this circuit may be presumed usually to be balanced. Conceivably, if they became unbalanced through either overactivity or inhibition of one as compared with the other, blood flow and calculated hepatic-portal resistance would change. Thus, it is possible that the early decrease and late return of increased HPR in resting horizontal hypertensive patients after splanchnicectomy (7) is due to an early unopposed, though normal, vasodilator activity followed by a moderation of that activity or by a return of "intrinsic vasoconstrictor tone," or both. Furthermore, it is possible that the sizeable "spontaneous" variations in EHBF observed after splanchnicectomy may be due to greater or lesser amounts of the remaining "vasodilator activity."

\section{SUMMARY AND CONCLUSIONS}

After splanchnic sympathectomy, reductions of hepatic blood flow in hypertensive patients tilted into the upright position are associated with sizeable decreases in arterial pressure and little change in average hepatic-portal resistance, whereas before operation reductions in EHBF in the upright position occur with little change in pressure and increases in HPR. It is concluded that the splanchnic sympathetic nervous system mediates the hepatic-portal vasoconstrictor response to the upright posture in hypertensive patients and probably also in normal subjects.

\section{ACKNOWLEDGMENTS}

The authors gratefully acknowledge the statistical analysis by Dr. Meyer $\mathrm{H}$. Halperin, the technical assistance of Miss Adele Rymut, and the photographic work of Miss Jane Holbrook.

\section{REFERENCES}

1. Culbertson, J. W., Wilkins, R. W., Ingelfinger, F. J., and Bradley, S. E., The effect of the upright posture upon hepatic blood flow in normal and hypertensive human subjects. J. Clin. Invest., 1947, 26, 1178.

2. Bradley, S. E., Ingelfinger, F. J., Bradley, G. P., and Curry, J. J., The estimation of hepatic blood flow in man. J. Clin. Invest., 1945, 24, 890.

3. Culbertson, J. W., Wilkins, R. W., Ingelfinger, F. J., and Bradley, S. E., The effect of the upright posture upon hepatic blood flow in normotensive and hypertensive subjects. J. Clin. Invest., 1950, 30, 305.

4. Smithwick, R. H., Surgery of the autonomic nervous system, in Operative Technic in Specialty Surgery, Cole, W. H. Appleton-Century-Crofts, Inc., New York, 1949, pp. 553-598.

5. Wilkins, R. W., and Culbertson, J. W., The effects of surgical sympathectomy upon certain vasopressor responses in hypertensive patients. $\mathrm{Tr}$. A. Am. Physicians, 1947, 60, 195.

6. Wilkins, R. W., Culbertson, J. W., and Smithwick, R. H., The effects of various types of sympathectomy upon vasopressor responses in hypertensive patients. Surg., Gyn. \& Obst., 1948, 87, 661.

7. Wilkins, R. W., Culbertson, J. W., and Halperin, M. H., The hemodynamic effects of sympathectomy in essential hypertension. Ann. Int. Med., 1949, 30, 291.

8. Fisher, R. A., Statistical Methods for Research Workers. Oliver \& Boyd, London, 1941, Ed. 8. 